\title{
1. Public administration and politics: the art of separation $^{1}$
}

\author{
Patrick Overeem
}

Many people argue that civil servants constantly make political decisions, and that it is not realistic to separate politics from administration. Of course, civil servants are in the political world because elected politicians are in theory their masters. However civil servants are not of the political world because it

is believed in many developed states that civil servants should be neutral and should not take sides.

(Harris, 1990, p. 10)

\section{'NOTHING IS MORE CENTRAL'}

To most people, the idea of a division within government between public administration on the one hand and politics on the other might not seem very problematic. Politicians are elected, public administrators appointed; the former make decisions, the latter prepare and execute them - that is roughly how the government works and should work. Notwithstanding the seemingly general acceptance of the arrangement, students of public administration have for over 70 years now vehemently criticized the very division (or dichotomy, as they call it) between politics and administration. According to the standard narrative in the literature, the acceptance of the dichotomy in American Public Administration ${ }^{2}$ before the Second World War was an aberration (Svara, 1998) and a mistake that has, luckily, been corrected in the decades afterwards. It has been increasingly realized, so the narrative goes, that public administration is neither separate from, nor hierarchically subordinate to, politics, indeed that the two are intermingled and complementary (Svara, 1999, 2001). Although real advancements are rare in the social sciences, this is at least a step with which the field ritually congratulates itself.

With the demise of the dichotomy the subject of the relation between public administration and politics has not disappeared from the agenda, however (Campbell \& Peters, 1998; Georgiou, 2014). Indeed, it has become more salient and puzzling ever since. What is the (actual and proper) relation between public administration and politics? This is arguably the key question in the field since its inception, at least in Western (that is Anglo-American and Continental European) Public Administration. As Waldo put it: 'Nothing is more central in thinking about public administration than the nature and interrelations of politics and administration' (1987, p. 91).

This chapter will explore, firstly, some historical antecedents of our high-modern understanding of and struggle with the relation between public administration and politics. Then,

This chapter is based on the more detailed argument in Overeem (2012).

2 Here I follow Waldo's example (1968, p. 443 n.1) to use Public Administration to refer to the academic field of study with that name and public administration to refer to the practices of government and governance studied in that field. For the sake of consistency, capitalization is also used for other disciplines (Political Science). 
I will briefly discuss two main orthodox views on the matter, followed by some powerful heterodox criticisms. Next, I consider two recent alternative views and assess them critically, after which I present my own understanding of the relation between public administration and politics as a constitutional issue. I conclude with some reflections on the stakes in this debate.

Two limitations should be noted. One is that this chapter deals only with (academic) ideas about the relation between public administration and politics, leaving aside the innumerable practices that have developed in various countries, levels of government, policy domains, and time periods (Matheson et al., 2007). This is not to deny the value of the ever-growing empirical literature on political-administrative relations, but only to restrict myself to the realm of theoretical argument, as befits this Handbook. The other limitation is that this chapter addresses the relation between public administration and politics only within the sphere of government (Raadschelders, 2003). I acknowledge, of course, that administrative scientists increasingly address forms of administration (or governance) beyond that sphere. I acknowledge also that, according to many theorists, politics can also be found in the worlds of business, civil society, private life, even animal life (De Waal, 1982). True as all this may be, the confrontation between public administration and politics primarily takes place within government, so the present discussion will be restricted to that sphere only.

\section{ONE PUZZLE, TWO SOLUTIONS}

To understand how public administration and politics interrelate (or not), it is necessary to see where our ideas on the topic have come from. Tracing back its conceptual origins shows that in the long history of political philosophy up until the eighteenth century (the long Western tradition from, say, Socrates to Kant) surprisingly little attention has been paid to the administrative side of government. Whatever we associate with public administration nowadays (be it the preparation and implementation of policies, the internal workings of public organizations, and so on) received hardly any attention by prominent thinkers in the tradition. It tended to be 'put aside as "practical detail" which clerks could arrange after the doctors had agreed upon principles,' as Wilson phrased it (1887, p. 199). This is telling; it underlines that public administration was always regarded as different from and secondary to politics.

Nonetheless, political philosophy does know a strong tradition of constitutional thinking concentrating on a major challenge, namely, to reconcile the requirement that government should be strong (and hence a unity, governed by rulers with expertise) with the opposite and equally important requirement that it should also be constrained (and hence divided and controlled by citizens or their representatives). Strength is needed to avoid the Scylla of anarchy and constraint to avoid the Charybdis of tyranny. The now two centuries old debate about the relation between public administration and politics can be regarded as a new chapter in this much longer constitutional tradition (Nieuwenburg \& Rutgers, 2001).

The best known and most influential response to the constitutional challenge just mentioned is of course the doctrine of the separation of powers (Vile, 1998). The very idea of separating and balancing powers (that is, institutions performing specific functions) was meant to contribute to the protection of political liberty. When the doctrine of the separation of powers was formulated and refined by Locke, Montesquieu, Madison, and others, public administration did, however, not yet have to be recognized as an important part of the state. The concept of the executive referred in particular to the monarchy (later the presidency) and to the powers to 
maintain order within the state and protect it against dangers from without, so what we now call the police and the military. The provision of education, welfare, healthcare, infrastructure, and other social goods were mostly located outside the state and tended to be much more limited than today or even non-existent. So, when the separation-of-powers doctrine was formulated, public administration was not given a place in it because it still had to develop. (This is one reason why the distinction politics/administration cannot simply be equated with legislative/executive. Another is that, obviously, public administration tends to exercise more governmental functions than the executive did and does, including even the formulation and adjudication of specific rules.)

When, during the eighteenth and nineteenth centuries, public administration gradually developed, this presented constitutionalists with a problem. They saw the rapid growth of parts of the state that had long remained relatively unimportant and that therefore had no recognized place under the constitutional sun. Public administration quickly came to outweigh the traditional branches of government in terms of tasks, staff, budgets, and ultimately power.

There were, and basically there still are, two diverging responses to this development. One response is to regard public administration as a threat to the legislative, executive, and judiciary. Like a cuckoo's young, it is feared to be pushing the others out of the nest. Hence, the response is to make the administrative apparatus subordinate to established constitutional powers. Their elevated status must be respected, and the separation of powers kept intact. This response follows the constitutionalist logic of legitimating and limiting might by right. Naturally associated with Montesquieu's De l'Esprit des Lois (1748 [1989]), let it be called the French approach.

The other response builds instead on the ideas formulated by Hegel in his Grundlinien der Philosophie des Rechts (1821 [1967]) and can hence be called the German approach. Typically drawing on organic conceptions of the state, it puts much more confidence in rational administration. It values public servants as neutral and competent guardians of the general interests, as a 'universal class,' as Hegel called them (1967, p. 303; see also Shaw, 1992). This approach typically draws a distinction between constitution (Verfassung) and administration (Verwaltung), in order to give the latter a separate, independent position besides or even above the traditional powers. In this view, public administration is too important to be interfered with. Emphasizing the importance of the unity of the state and supposing public administration represents that unity, it tends to reject the separation of powers or at least to relativize its importance.

These two responses have one important similarity: they both tend to set public administration apart from the established three branches. In the first case, however, this move is meant to constrain the growing power of the administrative state, while in the second it is meant to increase it. French thinkers like Tocqueville (1835-40 [2000]) and representatives of the emerging science administratif such as Bonnin (1812) and especially Vivien (1859) followed the first line of thought (see also Martin, 1987). They tried to give public administration a legitimate place within the state and integrate it in the constitutional framework of separated powers, while keeping it subordinate to politics. It was perfectly summarized some decades later by Chardon:

I ask you to recognize that a democratic republic like ours necessarily comprises two powers: the political and the administrative; the administrative being subordinate to the political, but nonetheless existing and living outside of politics in such a way that, in every affair, the citizens can easily make a judgment on the role of the politicians and on the role of the administrators. (1911, pp. 19-20) 
This line of thought has, however, remained largely unknown and has not exerted much influence on later Public Administration. By contrast, representatives of the German Verwaltungslehre, especially Von Stein $(1865,1887)$ and Bluntschli $(1876,1885)$, successfully developed the second line of thinking. Their view on the relationship between public administration and politics - albeit more nuanced than is often thought - soon became very influential when their neo-Hegelian approach was imported by the nascent study of public administration in America (Rosser, 2009; Sager \& Rosser, 2009). This explains in large part why the discipline has so often been out of tune with the American constitutional tradition (Bertelli \& Lynn, 2006; Spicer, 1995).

\section{SEPARATION OR SUBORDINATION}

The best-known classical formulations and defenses of a divide between public administration and politics are undoubtedly those of Woodrow Wilson, Frank J. Goodnow, and Max Weber. The two Americans represent the typical Hegelian (German) position distinguished earlier, while Weber was a genius of his own who developed a unique position deviating from both the German and French approaches.

In the position of Wilson and Goodnow the main emphasis is on the separation of administration from politics in order to protect the former against the latter. Wilson's classical essay The Study of Administration (1887) and Goodnow's book Politics and Administration (1900) have become the most important texts in this regard. Inspired by German organicism, both men strived for the administrative and political (even constitutional) reform of American government. For that purpose, administrative questions had to be separated from political questions (Wilson, 1887, p. 210). Admittedly, they particularly attempted to free administration from partisan and corrupt political intervention (the infamous spoils system), not from sound democratic politics, let alone from policy making. Notwithstanding this nuance, however, both clearly strived to disentangle administration from politics, favoring a subtle but robust dichotomy between the two. In doing so, they had not just a theoretical but above all a practical aim: reforming the US government and building an administrative state (O'Toole, 1987; Pestritto, 2005, 2007).

In Weber's approach, by contrast, the emphasis is rather on the subordination of administration to politics. He was strongly aware, like Wilson and Goodnow, that public servants are not passive instruments in the hands of politics but have their own will (1918 [1994], p. 160). But that, for him, was exactly where the danger lurked. Against the Hegelian view, he argued the importance of safeguarding politics from bureaucratic domination (Beamtenherrschaft). To curb this danger, and indeed to prevent chaos in post-revolutionary and post-war Germany, he supported strong charismatic political leadership, if necessary on a plebiscitary basis (Weber, 1919 [1994], p. 351).

Both positions - separation and subordination - can be understood not only by means of historical circumstances in which they developed (American Progressive reformism and the chaotic situation in post-First World War Germany, respectively), but also in light of traditional views, in both cases, on the legitimacy of public administration within the state. In America, this legitimacy was (and often still is) so dubious that Wilson and Goodnow felt they had to secure it, while in Germany it was so uncontested that Weber considered it pernicious. 
But however understandable both positions may be, they are both one-sided and should ideally be integrated: subordination and separation are both important. In the historiography of the subject, too little attention has been paid to the goals that these classical thinkers aimed at. For both Wilson and Goodnow on the one hand and for Weber on the other, the politics-administration dichotomy served as part of a broader program, namely the replacement of constitutionalism (limited government, the separation of powers) by more radical and unified alternatives (Carrese, 2005; Slagstad, 1988). This makes their thought truly revolutionary and, in my opinion, problematic.

\section{ADMINISTRATION WITH DISCRETION}

Until the 1930s, the dichotomy was generally, albeit not very intensely, endorsed in the American study of public administration (even though, ironically, the writings of Wilson and Weber on the subject were still largely unknown). It is traditionally regarded as part of a wider view that has become known as Public Administration's orthodoxy (Sayre, 1958; Waldo, 1948): the view, roughly, that administrators receive their orders directly from democratic politicians and then have their own scientifically proven ways to execute them efficiently. Although this simplistic view, which Lawler has aptly called 'scientific populism' (1988, pp. 50-3), appears to have been never generally endorsed at all (Bertelli \& Lynn, 2006, ch. 3; Lynn, 2001), the politics-administration dichotomy's association with it has seriously harmed its reputation.

Another important development with the same effect was that authors like Gulick (1933, pp. 60-1), Appleby (1949), and others started to identify the distinction between politics and administration with that between policy and administration. This re-conceptualization became very influential: increasingly it was believed that orthodox Public Administration had ascribed to administrators only a role of mindless automatons without any decision-making and policy-making role. This interpretation understandably attracted a lot of criticism. Two types in particular stood out.

Much empirical criticism, firstly, pointed out that public administration is in fact soaked in discretionary policy making and decision making (Demir \& Nyhan, 2008). Roughly since the 1970 s, moreover, systematic research showed an often very close interaction between politicians and (senior) public servants (Aberbach et al., 1981). Empirical objections were therefore primarily aimed at the idea of a separation between public administration and politics (much more than against its subordination). However strong this empirical evidence is, two things should be noted. The first is that these empirical findings did not deny an equally consistent pattern of differences and distance between politicians and public servants (Lee, 2001, 2006; Maynard-Moody \& Kelly, 1993, p. 89). The second is that, of course, empirical findings cannot falsify (nor corroborate) the normative claim that public administration and politics should be separated.

Normative criticism, secondly, was raised primarily against the notion of administrative subordination to and hence its possible instrumentalization by politics. Standard references were made to extreme cases like those of Adolf Eichmann and the Nazis more generally (for example, Long, 1952, p. 817; Roberts, 2019; Waldo, 1987, p. 93) - although the extreme politicization of the bureaucracy under Hitler has never been defended within Public Administration, not even by the staunchest followers of Weber. Alternatively, it has been 
argued that keeping public servants subordinate to political control or out of policy making could harm the quality of policies (Waldo, 1980, p. 69). Here again, the Hegelian appreciation of administrators as a 'universal class' with neutral competence shines through.

In both types of criticism, the concept of administrative discretion plays a crucial role. It is often argued that, because public servants (should) have discretionary space, they (should) therefore also codetermine policies and (should) thus engage in politics (for example, Rohr, 1989, pp. 23, 48-9). This argument is too rash, however. Discretionary space, even in the preparation of policy, is by definition restricted by legal and other limitations enacted by higher, usually political authorities (Dworkin, 1977, p. 31; Gulick, 1933, p. 61). Within these limitations, administrative action is legitimated by professional or moral norms, and for the rest by the practical wisdom and experience of the administrators themselves (Morgan, 1990). Administrative discretion is thus not inconsistent with a separated and hierarchical relation between politics and public administration, but rather presupposes it.

\section{COMPLEMENTARITY AND GOVERNANCE}

After rejecting the dichotomy between public administration and politics, administrative theorists started looking for a viable substitute (Mosher, 1982, p. 8). However, since they had lost sight of the original goal (giving public administration a legitimate but limited place in the constitutional framework), the criteria for proper alternatives remained unclear, resulting in a wealth of suggestions. Here I want to discuss only two of the most recent and most influential alternatives, namely the complementarity model and the concept of governance.

The most important contemporary author on the relation between public administration and politics is undoubtedly Svara. In a range of writings, he has criticized the concept of dichotomy and developed and defended his notion of complementarity (for example, 1998, 1999, 2001, 2006). In contrast to dichotomy, complementarity emphasizes that public administration and politics are not hierarchically ordered and opposed to each other, but rather on an equal footing and collaborating in a common pursuit. His elaborations of the complementarity model are often highly complex because they aim to provide not only a norm saying how public administration and politics should relate, but also an accurate depiction of how they do in fact relate already. Take, for instance, this key definition:

The complementarity of politics and administration holds that the relationship between elected officials and administrators is characterized by interdependency, extensive interaction, distinct but overlapping roles, and political supremacy and administrative subordination coexisting with reciprocity of influence in both policymaking and administration. Complementarity means that politics and administration come together to form a whole in democratic governance. (1999, p. 678)

So, complementarity combines a high degree of control by elected officials with a high level of independence for administrators, so that 'Politicians respect administrative competence and commitment' while 'Administrators are committed to accountability and responsiveness,' thereby reinforcing each other's legitimacy (Svara, 2001, p. 179). Thus conceived, the complementarity model nearly amounts to an ethical code of value commitments and desired interactions (Svara, 2002, p. 10).

The complementarity model, briefly summarized here, is currently the strongest alternative to the classical dichotomy model and has proven to be appealing to public sector professionals 
and academics alike (Demir, 2009). Still, the model has some obvious problems as well. One is that the model's elaborate and nuanced character affects its coherence and applicability. More importantly, the model paints too rosy a picture of political-administrative relations, as if power plays no role and as if officials from both sides simply live up to the ethos that the model describes (Harmon, 2006, p. 18). A quick look at practice shows that this is obviously not the case.

Another recent concept that has been proposed to unify public administration and politics is of course governance. Often contrasted with government, it refers to flexible network organizations, multi-actor policy making, deliberative decision making, public-private collaboration, and the involvement of societal actors and citizens besides the state (Van Kersbergen \& Van Waarden, 2001). Like the concept of complementarity, that of governance is strongly loaded with normativity as well as empirics. On the one hand, it is given highly positive associations: 'Governance implies importance. Governance implies legitimacy. Governance implies a dignified, positive contribution to the achievement of public purposes' (Frederickson, 1997, p. 87). On the other hand, it attempts to grasp in one concept an increasingly complex world of practices and experiences. Understood in this way, governance tends to blur important distinctions that have traditionally shaped Public Administration, such as public/private, state/ society, and indeed 'the distinctions between things political and things administrative' in order to 'reconcile the old politics-administration dichotomy' (Frederickson, 1997, p. 85).

The question is, however, whether the concept of governance really manages to do that. As Frederickson puts it, 'the windup is better than the pitch' (1997, p. 92). Although useful to describe a domain to which both public administration and politics belong, governance also blots out the undeniable differences and distance between them. Whereas complementarity still assumes the conceptual distinction between them, governance abandons that too. This is an analytical loss, but it also has practical implications as 'the use of governance as a surrogate for public administration masks the fundamental issue of what ought to be the role of non-elected public officials in a democratic polity' (Frederickson, 1997, p. 92) - thus the very constitutional puzzle our tradition of thinking about the relation between public administration and politics started with. Encompassing concepts like complementarity and governance are often part of unconstitutional and even utopian ways of thinking (for example, Harmon, 2006, pp. 131-6). They tend to conceal the tensions between public administration and politics rather than to bridge, let alone transcend them.

\section{A CONSTITUTIONAL PERSPECTIVE}

As various generations of administrative theorists have neglected the original puzzle that underlies our thinking about the relation between public administration and politics, it is time to give it pride of place again. This can be done by building upon the ideas of the Constitutional School that has emerged in Public Administration since the 1980s (Newbold, 2010; Newbold \& Rosenbloom, 2017). Its representatives, particularly Rohr (1986) but also Rosenbloom (1983), Spicer (2010), and others, have strongly defended the legitimacy of public administration within the constitutional order. They have, however, so far refrained from interpreting the relation between public administration and politics as a constitutional issue (rather than an issue of, for example, an efficient division of labor or of ethical norms for individual officials). 
There are, however, three arguments to do so. The first is simply that the relation between public administration and politics has all the formal characteristics of a constitutional issue: it is relatively general, it concerns the establishment, legitimation, distribution, and control of state power, and it combines empirical and normative considerations (see also Merry, 1978). Secondly, there is the argument of Waldo, who asked what states would be like if the very distinction and dichotomy between public administration and politics would be entirely absent. His answer is as relevant as disturbing: such states would be either utopian or totalitarian (1984, p. 232; 1987, p. 106). And indeed, fascist and communist regimes have - in different ways - sought to erase the line (Rugge, 2003, p. 180). Reversely, giving public administration a legitimate, separate, but also subordinate place under politics seems characteristic of constitutional democracies only. The third argument is that in practice the relation between public and public administration is already legally guarded as a constitutional matter. The Supreme Court of the United States, for instance, has consistently defended the mutual divide between administrators and (partisan) politics in order to protect individual rights and democratic freedom (Rosenbloom, 1984; Schultz, 1994; Stover, 1995). Other countries have rules and norms of the same kind.

But how can we reconcile the recognition of public administration within the state and its constitutional relation with politics with the established separation-of-powers doctrine? Again, in three ways. Administration can be found within the three branches, as a lower, politically controlled level. Or 'administrative character' can be considered an aspect that varies between them as being most present in the judiciary and least in the legislative. Most convincingly, however, administration can be considered the apparatus that is subordinate to and serves all three traditional three branches (see also Rohr, 1986). In this view, the legislative, executive, and judiciary have an elevated constitutional status in the sense that they can make final decisions and overrule administrative ones. For this reason, designating public administration 'the fourth branch' is a misnomer.

This interpretation of the relation between public administration and politics as a constitutional issue can help to better understand the practice of modern states, but it also harks back to the original puzzle with which it all started. In particular, it resumes the still-born French tradition of Montesquieu, Tocqueville, and Vivien - the tradition that went into oblivion when Hegelianism 'hijacked' the American study of public administration. According to the French, constitutionalist tradition the relation between public administration and politics is primarily a matter of distributing and balancing power in order to prevent both anarchy and tyranny.

\section{WHAT IS AT STAKE}

The debate about the relation between public administration and politics has become a complicated, confused, and inconclusive heap of historical, conceptual, empirical, and normative arguments. One recurring problem is that many conceptualizations of the distinction politics/ administration are needlessly strict. Specific ones (deciding/executing, elected/appointed) tend to be more vulnerable than more general ones (such as democracy/bureaucracy). Another source of confusion is the meaning of dichotomy. We can grant its critics that the term is perhaps needlessly sharp, but it has become quite common and it is useful (like separation of powers) to emphasize the important aspect of disentanglement. Ideally, we should replace it 
by a term that refers not only to the separation of public administration from politics, nor only to its subordination to it, but to both at the same time.

But how can public administration be separated from politics and subordinated to it at the same time? How to square that circle? Three related ideas can provide the beginning of a solution of this paradox. The first, suggested by Vivien (1859, p. 31), is that administration can be subordinated to politics when it comes to general rules (laws) and separate from it when it comes to particular rules (directives). The second, proposed by Rosenbloom (1984, p. 104), is that administration should be subordinated to policy politics but separated from partisan politics. And the third is that, as argued before, the notion of administrative discretion combines the subordination of public servants to politically set limitations while granting them a separate space to exercise their own professional and moral competence. However helpful these insights are, it is clear that we do need both sides of the coin: strict separation without subordination leads to Beamtenherrschaft, while strict subordination without appropriate separation leads to undue politicization. As in so many constitutional questions, evils on both sides must be avoided.

Upholding the barrier and hierarchy between public administration and politics is thus an exercise in the constitutional art of separation (Walzer, 1984) and an indispensable element of constitutional government. The stakes are high: administrative values need protection against encroachments by politics (Wilson and Goodnow), political values against encroachments by administration (Weber), and above all constitutional values against encroachments by the state as a whole (Carter, 1986). In thinking about the relation between public administration and politics, we must therefore above all apply the same logic as in the separation of powers: divide et impera, checks and balances, dividing the power of various parts of government and setting them up against each other, in order to protect political liberty.

\section{REFERENCES}

Aberbach, J.D., Putnam, R.D., \& Bert, A.R. (1981). Bureaucrats and Politicians in Western Democracies. Cambridge, MA: Harvard University Press.

Appleby, P.H. (1949). Policy and Administration. Tuscaloosa, AL: University of Alabama Press.

Bertelli, A.M., \& Lynn, L.E, Jr. (2006). Madison's Managers: Public Administration and the Constitution. Baltimore, MD: Johns Hopkins University Press.

Bluntschli, J.C. (1876). Lehre vom Modernen Stat. (Vol. 3: Politik als Wissenschaft). Stuttgart: Verlag der J.G. Cotta'schen Buchhandlung.

Bluntschli, J.C. (1885). The Theory of the State (trans. D.G. Ritchie, P.E. Metheson, \& R. Lodge). London: Clarendon.

Bonnin, C. (1812). Principes d'Administration Publique (3rd edn, vol. 1). Paris: Renaudiere.

Campbell, C.S.J. \& Peters, B.G. (1998). The politics/administration dichotomy: Death or merely change? Governance, 1(1): 79-99.

Carrese, P. (2005). Montesquieu, the Founders, and Woodrow Wilson: The evolution of rights and the eclipse of constitutionalism. In J. Marini \& K. Masugi (eds), The Progressive Revolution in Politics and Political Science: Transforming the American Regime (pp. 133-62). Lanham, MD: Rowman \& Littlefield.

Carter, L.H. (1986). Constitutional values and the administration of the public's affair. Public Administration Quarterly, 9(4): 434-48.

Chardon, G.H. (1911). Le Pouvoir Administratif. Paris: Perrin.

De Waal, F.B.M. (1982). Chimpanzee Politics: Power and Sex among Apes. Baltimore, MD: Johns Hopkins University Press. 
Demir, T. (2009). The complementarity view: Exploring a continuum in political-administrative relations. Public Administration Review, 69(5): 876-88.

Demir, T., \& Nyhan, R.C. (2008). The politics-administration dichotomy: An empirical search for correspondence between theory and practice. Public Administration Review, 68(1): 81-96.

Dworkin, R. (1977). Taking Rights Seriously. London: Duckworth.

Frederickson, H.G. (1997). The Spirit of Public Administration. San Francisco, CA: Jossey Bass.

Georgiou, I. (2014). Seeing the forest for the trees: An atlas of the politics-administration dichotomy. Public Administration Review, 74(2): 156-75.

Goodnow, F.J. (2003). Politics and Administration: A Study in Government. New Brunswick, NJ: Transaction Publishers. Originally published 1900.

Gulick, L. (1933). Politics, administration, and the 'New Deal.' Annals of the American Academy of Political and Social Science, 169: 55-66.

Harmon, M.M. (2006). Public Administration's Final Exam: A Pragmatist Restructuring of the Profession and the Discipline. Tuscaloosa, AL: The University of Alabama Press.

Harris, P. (1990). Foundations of Public Administration: A Comparative Approach. Hong Kong: Hong Kong University Press.

Hegel, G.W.F. (1967). Hegel's Philosophy of Right (trans. T.M. Knox). London: Oxford University Press. Originally published 1821.

Lawler, P.A. (1988). Public administration, constitutionalism, and political philosophy in America. Teaching Political Science, 15(2): 50-6.

Lee, M. (2001). Looking at the politics-administration dichotomy from the other direction: Participant observation from a state senator. International Journal of Public Administration, 24(4): 363-84.

Lee, M. (2006). Political-administrative relations in state government: A legislative perspective. International Journal of Public Administration, 29(12): 1021-47.

Long, N.E. (1952). Bureaucracy and constitutionalism. American Political Science Review, 46(3): $808-18$.

Lynn, L.E., Jr. (2001). The myth of the bureaucratic paradigm: What traditional public administration really stood for. Public Administration Review, 61(2): 144-60.

Martin, D.W. (1987). Déjà vu: French antecedents of American public administration. Public Administration Review, 47(4): 297-303.

Matheson, A., Weber, B., Manning, N., \& Arnould, E. (2007). Study on the Political Involvement in Senior Staffing and on the Delineation of Responsibilities between Ministers and Senior Civil Servants. OECD Working Papers on Public Governance, 2007/6. Paris, France: OECD Publishing.

Maynard-Moody, S.W., \& Kelly, M. (1993). Stories public managers tell about elected officials: Making sense of the politics-administration dichotomy. In B. Bozeman (ed.), Public Management: The State of the Art (pp. 71-90). San Francisco, CA: Jossey-Bass.

Merry, H.J. (1978). Constitutional Function of the Presidential-Administrative Separation. Washington, DC: University Press of America.

Montesquieu, C-L. (1989). The Spirit of the Laws (ed. A.M. Cohler, B.C. Miller, \& H.S. Stone). Cambridge: Cambridge University Press. Originally published 1748.

Morgan, D.F. (1990). Administrative phronesis: Discretion and the problem of administrative legitimacy in our constitutional system. In H.D. Kass \& B.L. Catron (eds), Images and Identities in Public Administration (pp. 67-86). Newbury Park, CA: Sage.

Mosher, F.C. (1982). Democracy and the Public Service (2nd edn). New York: Oxford University Press.

Newbold, S.P. (2010). Toward a constitutional school for American public administration. Public Administration Review, 70(4): 538-46.

Newbold, S.P., \& Rosenbloom, D.H. (2017). The Constitutional School of American Public Administration. New York: Routledge.

Nieuwenburg, P., \& Rutgers, M.R. (2001). Politics and administration: Some remarks on the conceptual roots of the dichotomy. In E.V. Heyen (ed.), Jahrbuch für Europäische Verwaltungsgeschichte (pp. 185-202). Baden-Baden, Germany: Nomos.

O'Toole, L.J. (1987). Doctrines and developments: Separation of powers, the politics-administration dichotomy, and the rise of the administrative state. Public Administration Review, 47(1): 17-25.

Overeem, P. (2012). The Politics-Administration Dichotomy: Toward a Constitutional Perspective. Boca Raton, FL: Taylor \& Francis. 
Pestritto, R.J. (2005). Woodrow Wilson and the Roots of Modern Liberalism. Lanham, MD: Rowman \& Littlefield.

Pestritto, R.J. (2007). The Progressive origins of the administrative state: Wilson, Goodnow, and Landis. Social Philosophy \& Policy, 24(1): 16-54.

Raadschelders, J.C.N. (2003). Government: A Public Administration Perspective. London/New York: Routledge.

Roberts, A. (2019). Shaking hands with Hitler: The politics-administration dichotomy and engagement with fascism. Public Administration Review, 79(2): 267-76.

Rohr, J.A. (1986). To Run a Constitution: The Legitimacy of the Administrative State. Lawrence, KS: University of Kansas Press.

Rohr, J.A. (1989). Ethics for Bureaucrats: An Essay on Law and Values (2nd, revised and expanded edn). New York: Marcel Dekker.

Rosenbloom, D.H. (1983). Public administrative theory and the separation of powers. Public Administration Review, 43(3): 219-27.

Rosenbloom, D.H. (1984). Reconsidering the politics-administration dichotomy: The Supreme Court and public personnel management. In J. Rabin \& J.S. Bowman (eds), Politics and Administration: Woodrow Wilson and American Public Administration (pp. 103-18). New York: Marcel Dekker.

Rosser, C. (2009). Woodrow Wilson's administrative thought and German political theory. Public Administration Review, 70(4): 547-56.

Rugge, F. (2003). Administrative traditions in Western Europe. In B.G. Peters \& J. Pierre (eds), Handbook of Public Administration (pp. 177-91). London: Sage.

Sager, F., \& Rosser, C. (2009). Weber, Wilson, and Hegel: Theories of modern bureaucracy. Public Administration Review, 69(6): 1136-47.

Sayre, W.S. (1958). Premises of public administration: Past and emerging. Public Administration Review, 18(1): 102-5.

Schultz, D.A. (1994). Supreme Court articulation of the politics-administration dichotomy. In A. Farazmand (ed.), Handbook of Bureaucracy (pp. 413-29). New York: Marcel Dekker.

Shaw, C.K.Y. (1992). Hegel's theory of modern bureaucracy. American Political Science Review, 86(2): $381-9$.

Slagstad, R. (1988). Liberal constitutionalism and its critics: Carl Schmitt and Max Weber. In J. Elster \& R. Slagstad (eds), Constitutionalism and Democracy (pp. 103-29). Cambridge: Cambridge University Press.

Spicer, M.W. (1995). The Founders, the Constitution, and Public Administration: A Conflict in World Views. Washington, DC: Georgetown University Press.

Spicer, M.W. (2010). In Defense of Politics in Public Administration: A Value Pluralist Perspective. Tuscaloosa, AL: The University of Alabama Press.

Stover, C.P. (1995). The old public administration is the new jurisprudence. Administration \& Society, 27(1): 82-106.

Svara, J.H. (1998). The politics-administration dichotomy model as aberration. Public Administration Review, 58(1): 51-8.

Svara, J.H. (1999). Complementarity of politics and administration as a legitimate alternative to the dichotomy model. Administration \& Society, 30(6): 676-705.

Svara, J.H. (2001). The myth of the dichotomy: Complementarity of politics and administration in the past and future of public administration. Public Administration Review, 61(2): 176-83.

Svara, J.H. (2002). Being apart but living together: The ideal types and the reality of the politics-administration dichotomy. Paper read at the Paul van Riper symposium preceding the annual conference of the American Society for Public Administration, Phoenix, AZ, March 23.

Svara, J.H. (2006). Complexity in political-administrative relations and the limits of the dichotomy concept. Administrative Theory \& Praxis, 28(1): 121-39.

Tocqueville, A. (2000). Democracy in America (trans. H.C. Mansfield \& D. Winthrop). Chicago, IL: University of Chicago Press. Originally published 1835-40.

Van Kersbergen, K., \& Van Waarden, F. (2001). Shifts in Governance: Problems of Legitimacy and Accountability. The Hague: NWO Netherlands Organization for Scientific Research.

Vile, M.J.C. (1998). Constitutionalism and the Separation of Powers (2nd edn). Indianapolis, IN: Liberty Fund. 
Vivien, A.F.A. (1859). Études Administratives (3rd edn). Paris: Guillaumin.

Von Stein, L. (1865). Die Lehre von der Vollziehenden Gewalt, ihr Recht und ihr Organismus: Mit Vergleichung der Rechtszustände von England, Frankreich und Deutschland. Stuttgart: Verlag der J.G. Cotta'schen Buchhandlung.

Von Stein, L. (1887). Handbuch der Verwaltungslehre (Vol. 1: Der Begriff der Verwaltung und das System der Positiven Staatswissenschaften) (3rd edn). Stuttgart: Verlag der J.G. Cotta'schen Buchhandlung.

Waldo, D. (1948). The Administrative State: A Study of the Political Theory of American Public Administration. New York: Ronald Press.

Waldo, D. (1968). Public administration. Journal of Politics, 30(2): 443-79.

Waldo, D. (1980). The Enterprise of Public Administration: A Summary View (5th edn). Novato, CA: Chandler \& Scharp.

Waldo, D. (1984). The perdurability of the politics-administration dichotomy: Woodrow Wilson and the 'identity crisis' of public administration. In J. Rabin \& J.S. Bowman (eds), Politics and Administration: Woodrow Wilson and American Public Administration (pp. 219-33). New York: Marcel Dekker.

Waldo, D. (1987). Politics and administration: On thinking about a complex relationship. In R.C. Chandler (ed.), A Centennial History of the American Administrative State (pp. 89-112). New York: Free Press.

Walzer, M. (1984). Liberalism and the art of separation. Political Theory, 12(3): 315-30.

Weber, M. (1994). Parliament and government in Germany under a new political order: Towards a political critique of officialdom and the party system. In P. Lassman \& R. Speirs (eds), Political Writings (pp. 130-271). Cambridge: Cambridge University Press. Originally published 1918.

Weber, M. (1994). The profession and vocation of politics. In P. Lassman \& R. Speirs (eds), Political Writings (pp. 309-69). Cambridge: Cambridge University Press. Originally published 1919.

Wilson, W. (1887). The study of administration. Political Science Quarterly, 2(1), 197-222. 